\title{
PROMOTING SAFETY THROUGH LAW, NATIONAL AND INTERNATIONAL, AND BY OTHER MEANS
}

\author{
KJ Keith*
}

The Woodhouse family, friends of Sir Owen Woodhouse and the law faculties of the Victoria University of Wellington and the University of Auckland decided on the occasion of what would have been Sir Owen Woodhouse's 100th birthday that a fellowship and lectureship should be established in recognition of the great contributions he has made to law and policy in New Zealand and beyond. The fellows and lecturers are not to see themselves as limited to the law and are encouraged to address broader matters challenging people here and abroad. Sir Kenneth Keith gave the inaugural Sir Owen Woodhouse Memorial Lecture in Wellington on 29 August 2017 and in Auckland on 30 August 2017. The address considers in turn the dangers and perils at work, at sea and on the battlefield. It reflects on New Zealand's accident compensation scheme and suggests possible extensions to the scheme.

$\ldots$ out of this nettle, danger, we pluck this flower, safety. ${ }^{1}$

I have learned a great deal from my mentors over many years. For more than 50 years, Owen Woodhouse was a major one and indeed continues to be. He emphasised the importance of getting the question right, of establishing the facts, of seeking out the relevant values, policies and principles, of understanding the need to balance competing values, policies and principles and of the ongoing assessment of the impact of the law that results. Clear thinking, clear writing and getting the first sentence right were also critical. So too was the international and comparative material. What could we learn from the experience of others?

In terms of my topic tonight, many perils and dangers present themselves. Consider the Korean Peninsula, the 2004 Indian Ocean and 2011 Fukushima earthquakes and tsunami, the war, famine and cholera epidemic threatening 2,000,000 Yemenis, the storms and flooding in Texas and the much more extensive flooding in Bangladesh, India and Nepal in which it is reported 1,200 have died. But tonight

* Emeritus Professor, School of Law, Victoria University of Wellington, New Zealand.

1 William Shakespeare King Henry IV, Part 1, Act 2, Scene 3. 
I do not address those matters in respect of which law, national and international, does have an important but inadequately developed role. ${ }^{2}$

Rather, I will consider dangers and perils at work, at sea and on the battlefield. I will take them in that order, but return to the accident compensation scheme and its possible extension at the end.

In terms of dangers at work I go back to the time of Edward Tregear and Franz Kafka and with getting the question right and assembling the facts, including relevant legislation. The year is 1897 , six years after Tregear had been appointed by John Ballance, the Premier, and William Pember Reeves, the Minister of Labour, as the first Secretary for Labour in New Zealand and Chief Inspector of Factories and 10 years before Kafka, a brilliant young lawyer, was appointed to the Workers Accident Insurance Institute of the Kingdom of Bohemia in Prague. In that year, Walter Gorst Clay, barrister of the Inner Temple, published a lengthy article on the law of employers' liability and insurance against accidents in the second volume of the Journal of the Society of Comparative Legislation, a valuable journal which unfortunately no longer exists but which was cited recently by the Chief Justice. ${ }^{3}$

In his very first sentence - to return to that matter emphasised by Sir Owen - Mr Gorst Clay sees the existing law of employers' liability as being based on two essentially distinct principles compensation for a wrong and indemnity against a peril. The first had been developed by the courts, the second by legislatures. He was able to state the issue succinctly in that way because he had studied the law and particularly the legislation and some of the practice of fully 51 jurisdictions - the United Kingdom and many of its colonies, many of the states of the United States and 15 European states. He gave particular attention to the German law of insurance against accidents adopted in 1884, during Chancellor Otto von Bismarck's long reign. That law, he considered, was probably the most successful part of the social legislation undertaken in Germany at that time.

Gorst Clay in the light of his review - which just predated the first Workmen's Compensation Act 1897 in the United Kingdom and by three years that in New Zealand - recorded, still on the first of his 111 pages, that the conviction appeared to be gaining ground that the idea of employers' liability the court-made law - should be abandoned altogether and the problem of work accidents should be

2 To take just four references relating to reduction (or mitigation or prevention), readiness (or preparedness), response and recovery, see United Nations Office for Disaster Risk Reduction Sendai Framework for Disaster Risk Reduction 2015-2030 (March 2015); Draft articles on the protection of persons in the event of disasters UN doc A/71/10 (2016); International Federation of the Red Cross and Red Crescent Societies Guidelines for the Domestic Facilitation and Regulation of International Disaster Relief and Initial Recovery Assistance (November 2007); and Law Commission Final Report on Emergencies (NZLC R22, 1991). See also the very extensive preparatory work leading to those documents.

3 Walter Gorst Clay "The Law of Employers' Liability and Insurance against Accidents" (1897) 2 JSCL 1. 
seen as essentially one of putting on a sound economic basis a portion of the necessary taxation of the state - by legislation, of course. He elaborated the reason in these terms $:^{4}$

For as the care of the injured workman and the support of those whom, were he uninjured, he would have

to maintain, fall in the last resort upon the State, it is the duty of the State to provide that the funds required

for the discharge of this liability shall be raised in an equitable manner from among its subjects.

A similar appeal to community responsibility, to recall the first principle in the Woodhouse Report ${ }^{5}$ appeared in the following year in New Zealand in the preamble to the Old-age Pensions Act 1898. Parliament declared that it was equitable that deserving persons who during their prime of life had helped to bear the public burden of the colony by the payment of taxes and to open up its resources by their labour and skill should receive a pension in their old age. ${ }^{6}$

Gorst Clay's paper on its second page focuses on a matter which he saw as essentially separate from compensation for work injury: that matter was the precautions to be taken against accidents through state regulation, supported by the enforcement of penal provisions requiring the taking of care. The legislation he reviews showed that that clear separation had become well established in principle as well as in practice some decades earlier. Even though the proposition that tort liability for negligence would help promote safe systems of work was to be heard over much of the following century, the essential rejection of that proposition, or at least its very limited role, had long been reflected in the imposition of distinct obligations on the operators of factories, mines, ships and shops and offices to protect their workers. Consider the great efforts of Shaftesbury ${ }^{7}$ and Macaulay ${ }^{8}$ in the middle of the 19th century. That law, supported by an inspectorate and criminal liability, is to be found in New Zealand legislation dating back to at least 1846 as appears from an 1896 publication, The Labour Laws of New Zealand, prepared by Edward Tregear. ${ }^{9}$ A publication a decade or so later would have included legislation designed to give effect to the first international labour conventions, adopted in $1906 .{ }^{10}$ They prohibited the use of white phosphorous in the match industry and night work for

4 At 1.

5 Compensation for Personal Injury in New Zealand: Report of the Royal Commission of Inquiry (Government Printer, December 1967) [Woodhouse Report].

6 The preamble to the Old-age Pensions Bill 1896 (95-1) (also promoted by the Premier RJ Seddon) ended in this way: "should in old age be protected by the colony against the risk of want".

7 See for example Georgina Battiscombe Shaftesbury: A biography of the Seventh Earl 1801-1885 (Constable, London, 1974). He is commemorated by the Shaftesbury Memorial Fountain in Piccadilly Square.

8 See for example his 1846 speech in the House of Commons in support of a Bill limiting the labour of young persons in factories to 10 hours a day: John Clive and Thomas Pinney (eds) Thomas Babington Macaulay: Selected Writings (University of Chicago Press, Chicago, 1972) at 193.

9 Department of Labour The Labour Laws of New Zealand (1896).

10 International Convention respecting the Prohibition of the Use of White (Yellow) Phosphorus in the Manufacture of Matches 99 BFSP 986 (signed 26 September 1906, entered into force 1 January 1912); and 
women employed in industry - an early sign that employers willing to undertake such obligations wished to be protected by treaty from foreign employers, who would otherwise be free of such obligations. That argument of foreign cheating was one which Samuel Plimsoll had already had to face in getting his essential safety measure protecting seafarers established. ${ }^{11}$ The preambles to the treaties accordingly referred to the desire of the state parties to facilitate the protection of working people by the adoption of common provisions.

I have so far mentioned several notable individuals, including lawyers, and legislation and treaties, but not the work of courts, except incidentally. The Tregear publication, like Gorst Clay's survey, includes the Employers' Liability Acts from 1882 to 1892, which chipped away at the extraordinary 1837 decision of Lord Abinger CB and his fellow Barons in Priestley v Fowler. ${ }^{12}$ It is interesting for me - and I hope for others - to go back to that case. By that time the common law judges had established that an individual was liable for damages caused to another by that person's fault, even if unintentional. Next, a master or employer could be vicariously liable to a third person for their servants' negligent conduct in the course of that employment. But what of the case, presented to Lord Abinger CB and his colleagues, of physical harm caused by the negligent conduct of one servant to another? Could the master be held liable to the injured servant? The case, said the Barons, was unprecedented: "We are therefore to decide the question upon general principles and in doing so we are at liberty to look at the consequences of a decision the one way or the other." ${ }^{13}$ The judgment continues with these hypotheticals: ${ }^{14}$

If the master be liable to the servant in this action, the principle of that liability will be found to carry us to an alarming extent. He who is responsible by his general duty, or by the terms of his contract, for all the consequences of negligence in a matter in which he is the principal, is responsible for the negligence of all his inferior agents. If the owner of the carriage is therefore responsible for the sufficiency of his carriage to his servant, he ... is responsible for the negligence of his coach-maker, or his harness-maker, or his coachman. The footman, therefore, who rides behind the carriage, may have an action against his master for a defect in the carriage owing to the negligence of the coach-maker, or for a defect in the harness arising from the negligence of the harness-maker, or for drunkenness, neglect, or want of skill in the coachman; nor is there any reason why the principle should not, if applicable in this class of cases, extend to many others.

International Convention respecting the Prohibition of Night Work for Women in Industrial Employment 100 BFSP 794 (signed 26 September 1906, entered into force 14 January 1912). New Zealand withdrew from the second Convention in 1982, along with related International Labour Organization conventions.

11 See Nicolette Jones The Plimsoll Sensation: The Great Campaign to Save Lives at Sea (Little, Brown Book Group, London, 2006).

12 Priestly v Fowler (1837) 3 M \& W 1, 150 ER 1030 (Exch).

13 At 5 .

14 At 5 . 
The Court continues with suggested liabilities in respect of other classes of domestic servants the chambermaid, the upholsterer, the cook, the butcher and the builder. You will notice the emphasis on servants. The Court essentially concludes the case against the injured servant with this assessment: "The inconvenience, not to say the absurdity of these consequences, afford a sufficient argument against the application of this principle to the present case."15

In that largely unreasoned and unprincipled way, the common servant doctrine or fellow employment rule was established with serious consequences for those injured at work across the common law world, including the United States. ${ }^{16}$ It is striking that in 1939, or fully 100 years later, the House of Lords, while finding that the doctrine was based on personal apprehension rather than on principle and that "there [were] none to praise, and very few to love" it, held that the doctrine could not be overthrown by judicial decision. ${ }^{17}$ It was too well established and it had had legislative recognition. ${ }^{18}$

The rule was not finally abolished in New Zealand until 1936 and in the United Kingdom in $1948 .{ }^{19}$ It is tempting - but I resist - to compare Lord Abinger CB's reasoning with that to be found in a judgment given in the House of Lords 95 years later in the midst of the Great Depression in which the parable of the Good Samaritan was given significant weight in a ruling favouring the plaintiff in respect of alleged personal injury based on fault, a ruling with potentially extremely wide-ranging consequences. $^{20}$

Rather, I mention some relevant facts, as Sir Owen would have insisted. They relate to a very different type of transport from that on which Lord Abinger CB and his colleagues focused. By the 1830 s, the time of the decision, railway construction and operation in the United Kingdom were developing rapidly with about 500 miles of track and up to 900 workers who can hardly be thought of as servants serving along with other servants in one household - the case Lord Abinger CB and his colleagues had in mind. ${ }^{21}$ Further, as an effect and cause of railway development came big increases in mining and metallurgy and the use of the blast furnace. The rapidly developing industrial revolution

15 At 5 .

16 See especially Farwell v Boston \& Worcester RR Corp 45 Mass 49 (Mass 1842).

17 Radcliffe v Ribble Motor Services Ltd [1939] AC 215 (HL) at 223.

18 At 239

19 Law Reform Act 1936, s 18; and Law Reform (Personal Injuries) Act 1948 (UK), s 1.

20 Donoghue v Stevenson [1932] AC 562 (HL) at 580 per Lord Atkin, who also sat in Radcliffe, above n 17.

21 See the information summarised in Carl A Auerbach and others The Legal Process: An Introduction to Decision-Making by Judicial, Legislative, Executive, and Administrative Agencies (Chandler Publishing Company, San Francisco, 1961) at 20. This book was very influential in the early years of the Legal System course at the Victoria University of Wellington when that course replaced Roman Law in 1960. The first case included in the book was Priestley v Fowler, above n 12, and the third Farwell, above n 16. 
with its manifold dangers to the increasing number of industrial workers and resulting serious injury and deaths, the efforts of the reformers I mentioned earlier and the related legislation appear to have passed the Barons by. You may agree, I trust, with my assessment that the 1837 ruling was extraordinary, both as a matter of principle and fact.

I move to a second place of peril, of danger, the sea. Edward Tregear included among his collection of labour legislation that which gave particular protections to seafarers. ${ }^{22}$ For at least six centuries national legislation had required masters of ships to go to the aid of those in distress at sea. That obligation took general treaty form only in $1910,{ }^{23}$ and was included in New Zealand shipping legislation three years later in these terms: ${ }^{24}$

The master or person in charge of a ship shall, so far as he can do so without serious danger to his own ship, her crew, and passengers (if any), render assistance to every person, even if such person is a subject of a foreign State at war with His Majesty, who is found at sea in danger of being lost; and if he fails to do so he commits a crime.

That duty has been accompanied by a quid pro quo since at least 1566. In that year Pope Pius V, in calling on fishing vessels to come to the aid of those in peril, provided the balance - payment should be made to those who took that action. ${ }^{25}$ Some law and economics scholars, in addressing the law concerning rescue, fail to mention the relevant legislation and treaties and put the matter essentially in economic terms as regards the incentives they see underlying tort law. ${ }^{26}$ But surely, as Gilbert Gidel, a great French law of the sea expert, has put it, the ideas of humanity at the base of the 1910 Convention are above all discussion; the obligation of assistance is demanded by humanity ${ }^{27}$ - a word which appeared often in Sir Owen's thinking about injury prevention, rehabilitation and compensation, to quote the title of the draft Bill which was annexed to the early Law Commission report on injury

22 See for example the very extensive Shipping and Seamen Act 1877.

23 Convention for the Unification of Certain Rules of Law respecting Assistance and Salvage at Sea 103 BFSP 434 (23 September 1910).

24 Shipping and Seamen Amendment Act 1912, s 7(1). See ss 7(2) and 8 in respect of the payment of salvage.

25 See Gilbert Gidel Le droit international public de la mer: Le temps de paix (reprint, Topos, Vaduz (Liechtenstein), 1981) vol 1 at 369, n 2.

26 Notably William M Landes and Richard A Posner The Economic Structure of Tort Law (Harvard University Press, Cambridge (Mass), 1987) at 100-102, 142-148 and 250-751; and William M Landes and Richard A Posner "Salvors, Finders, Good Samaritans, and Other Rescuers: An Economic Study of Law and Altruism" (1978) 7 JLS 83 at 100-108.

27 Gidel, above n 25. 
prevention and recovery. ${ }^{28}$ Note the careful sequence of the three nouns in that title and the avoidance of any reference to accident.

To move to my third area, an obligation of assistance to those in distress has also long been recognised in another place of peril - the battlefield. I go back only to 1859 , to Solferino. ${ }^{29}$ Henry Dunant, a Swiss banker, in arranging succour for the casualties in their thousands caused by that dreadful battle, proceeded on the basis of siamo tutti fratelli - we are all brothers. No line was to be drawn between friend and foe. His efforts, with others of his compatriots, led to the formation in 1863 of what became the International Committee of the Red Cross and the adoption in 1864 of the First Geneva Convention for the Amelioration of the Condition of the Wounded in Armies in the Field. ${ }^{30}$ It provided for the protection, as neutral, of hospitals and ambulances and of those who work there. It also protected houses that took care of the wounded. The generals were to issue an appeal to the humanity - that word again - of the inhabitants to bring help to the wounded; those who did so were to remain free. Humanity, you will not be surprised to hear, is the first of the fundamental principles of the International Red Cross and Red Crescent Movement. Is the demand of humanity too often ignored by those who think only in narrow-market, zero-sum terms?

Another name from the 1860 s is Florence Nightingale. She was flatly opposed to Dunant's proposals for National Red Cross Societies. She saw their suggested responsibilities as belonging to governments alone. Governments should not be able to avoid those responsibilities by encouraging the formation of such organisations. ${ }^{31}$ She failed in that opposition, as appears from the critical roles played by the now 190 national societies in times of danger and emergencies. Much more important and successful was her insistence on accurate statistics. By collecting the facts about military deaths she was able to show that death and disease were greater in British military barracks than on the Crimean battlefield. She presented that information graphically through pie charts, a very early user of that powerful visual aid. ${ }^{32}$ Those charts were not just descriptive; they were prescriptive, aimed at persuading the government to improve military hygiene. She took on the army's top brass and was successful in that endeavour. In August 2017, the Australian Chief Scientist declared that she should be known not as the Lady with the Lamp, but as the Lady with the Logarithm or the Patron Saint of

28 Law Commission Personal Injury: Prevention and Recovery: Report on the Accident Compensation Scheme (NZLC R4, 1988) Appendix B at 94.

29 See Henry Dunant A Memory of Solferino (reprint, International Committee of the Red Cross, Geneva, 1986).

30 Convention for the Amelioration of the Condition of the Wounded in Armies in the Field 129 CTS 361 (signed 22 August 1864, entered into force 22 June 1865).

31 Pierre Boissier From Solferino to Tsushima: History of the International Committee of the Red Cross (Henry Dunant Institute, Geneva, 1985) at 42.

32 See for example JM Keith "Florence Nightingale: statistician and consultant epidemiologist" (1988) 35 INR 147. 
Mathematics. ${ }^{33} \mathrm{He}$ drew several lessons from her life. The first was that mathematics was critical to our lives and societies and the last that evidence was to be used to make a difference, instancing healthcare policy. Nightingale also commented, in correspondence with George Grey, on lessons to be drawn from the first New Zealand census, again suggesting, in terms of prescription, how hygiene among Māori populations might be improved. In one of her letters, she said to Grey, "[y]ou will do a noble work in New Zealand. But pray think of your Statistics", a word she emphasised by capitalising the initial "S". 34

In 1863 came the first detailed statement of the laws of war. It has at its core humanity competing with military necessity. It is General Orders No 100 issued by President Lincoln for the armies of the North in that very destructive Civil War. ${ }^{35}$ Francis Lieber, who had fought against Napoleon's forces and had sons on both sides of that American war, prepared that text. In 1864 the principles appear, in very short form, in the four laws for Waikato stated by Hēnare Taratoa for the Battle of Gate Pā, at which 250 Ngāi Te Rangi warriors defeated a British force of almost 2,000: the laws provided that unarmed soldiers were to be saved as were the wounded or captured and soldiers who fled to the house of a priest; unarmed Pākehā, women and children would be spared. ${ }^{36}$

That body of law has been much elaborated over the following 150 years and has been extended beyond the sick and wounded in the field: in 1899 to the sick, wounded and shipwrecked at sea, in 1929 to prisoners of war and in 1949 to civilians in occupied territory. ${ }^{37}$ In the mid-1970s important additions were made in respect of internal armed conflicts, methods and means of warfare and

33 Interview with Professor Alan Finkel, Australian Chief Scientist (Robyn Williams, Ockham's Razor, ABC Radio National, 20 August 2017).

34 Letter from Florence Nightingale to George Grey (Governor of New Zealand) regarding the Governor's construction of a hospital (28 July 1863).

35 For a recent account, see John Fabian Witt Lincoln's Code: The Laws of War in American History (Free Press, New York, 2012). The Code appears in an annex.

36 See for example Vincent O'Malley "Maori Rules of War At Gate Pa" in New Zealand Red Cross Wars, Laws and Humanity: New Zealand's Engagement with International Humanitarian Law (New Zealand, 2015) 4.

37 Geneva Convention for the Amelioration of the Condition of the Wounded and Sick in Armed Forces in the Field of 12 August 194975 UNTS 31 (opened for signature 12 August 1949, entered into force 21 October 1950); Geneva Convention for the Amelioration of the Condition of the Wounded, Sick and Shipwrecked Members of the Armed Forces at Sea of 12 August 194975 UNTS 85 (opened for signature 12 August 1949, entered into force 21 October 1950); Geneva Convention relative to the Treatment of Prisoners of War of 12 August 194975 UNTS 135 (opened for signature 12 August 1949, entered into force 21 October 1950); Geneva Convention relative to the Protection of Civilian Persons in Time of War of 12 August 194975 UNTS 287 (opened for signature 12 August 1949, entered into force 21 October 1950); Convention (III) for the Adaptation to Maritime Warfare of the Principles of the Geneva Convention of 22 August 1864187 CTS 443 (adopted 29 July 1899, entered into force 4 September 1900); and Convention relative to the Treatment of Prisoners of War 118 LNTS 343 (adopted 27 July 1929, entered into force 19 June 1931). The 1949 Geneva Conventions are scheduled to the Geneva Conventions Act 1958. 
improved means of implementation. ${ }^{38}$ These treaties have carried forward the proposition introduced into one of the conventions adopted in 1899 at the Hague Peace Conference on the initiative of Frederic de Martens, a leading Russian diplomat and lawyer. ${ }^{39}$ A 1977 version of what is known as the Martens Clause reads as follows: ${ }^{40}$

In cases not covered by this Protocol or by other international agreements, civilians and combatants remain under the protection and authority of the principles of international law derived from established custom, from the principles of humanity and from the dictates of public conscience.

The International Court of Justice in its Nuclear Weapons opinion of 1996, in setting out the cardinal principles of the fabric of international humanitarian law, saw that clause, the continuing existence and applicability of which was not to be doubted, as an affirmation that the principles and rules of humanitarian law apply to nuclear weapons. In saying that, it rejected the arguments made by the Russian Federation and the United States, among others. ${ }^{41}$

Out of all the history of the elaboration, successful applications and dreadful breaches of this law over the centuries I touch briefly on one matter which has been prominent recently: that matter is Security Council Resolution 2334 relating to the Middle East adopted on 23 December 2016 in the last days of New Zealand's most recent two-year membership of the Council. New Zealand's action in cosponsoring the Resolution and voting for it along with 13 of the 14 other members, including France, Japan, Spain and the United Kingdom, with the United States abstaining, has been the subject of much ill-informed comment, including that by the newly installed New Zealand Foreign Affairs Minister that the Resolution was "premature". ${ }^{42}$ May I make four points about the Resolution:

(1) It reaffirms that the occupied Palestinian territories are subject to the Fourth Geneva Convention of 1949 concerning the protection of civilians in armed conflict, including its

38 Protocol Additional to the Geneva Conventions of 12 August 1949, and relating to the Protection of Victims of International Armed Conflicts (Protocol I) 1125 UNTS 3 (opened for signature 8 June 1977, entered into force 7 December 1978) [First Additional Protocol]; and Protocol Additional to the Geneva Conventions of 12 August 1949, and relating to the Protection of Victims of Non-International Armed Conflicts (Protocol II) 1125 UNTS 609 (opened for signature 8 June 1977, entered into force 7 December 1978). The 1977 Additional Protocols were added to the schedules in the 1958 Act by the Geneva Conventions Amendment Act 1987.

39 Convention (II) with respect to the Laws and Customs of War on Land 187 CTS 429 (adopted 29 July 1899 , entered into force 4 September 1900).

40 Article 1(2) of the First Additional Protocol, above n 38.

41 Legality of the Threat or Use of Nuclear Weapons (Advisory Opinion) [1996] ICJ Rep 226 at 259-260.

42 Radio New Zealand "Brownlee's first 48 hours" (4 May 2017) <www.radionz.co.nz>; and Audrey Young "Brownlee won't be describing UN's Israel resolution as 'premature' again says PM" New Zealand Herald (online ed, New Zealand, 8 May 2017). 
unqualified prohibition on the transfer by a state of parts of its own civilian population into territories it occupies in the course of armed conflict.

(2) That position had been taken by the Legal Adviser to the Israeli Ministry of Foreign Affairs in a letter to the Office of the Prime Minister as early as November $1967 ;{ }^{43}$ the International Court of Justice ruled unanimously to the same effect in 2004;4 the December 2016 Resolution cites that opinion - the first such recognition by the Council of that ruling by the principal judicial organ of the United Nations;

(3) The Resolution condemned all acts of violence against civilians, called for immediate steps to end them and called on both parties to act on the basis of international law; given such provisions, I do not see the Resolution as unbalanced.

(4) The Fourth Convention was in draft, the Tokyo draft, before World War II and was to be the subject of a diplomatic conference in 1940; the International Committee of the Red Cross commentary to the Convention remarks that had the draft been adopted civilians in occupied countries would have received protection: ${ }^{45}$

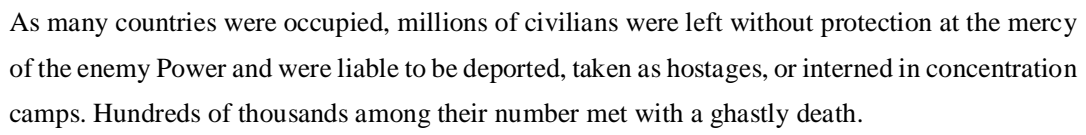

As promised, I return to work injuries, their prevention, rehabilitation and compensation and the possible extension of the current scheme. I return to the time of Edward Tregear, William Pember Reeves and Franz Kafka and their essential understanding that the promotion of safety at work and the rehabilitation and compensation of persons injured at work were two distinct matters; that was so even though they could be administered by the one body - as was the case in Germany, Bohemia and elsewhere.

I say a little about such bodies in part because they relate to the work of the next name on my chronological list - Albert Thomas - and to proposals Sir Owen has made down the years. The German associations and those in Austria were formed by groups of employers within a particular industry. Their boards had equal numbers of employer and worker delegates. They had large powers of selfmanagement in setting and gathering the premiums from the employers and making decisions on compensation for work injuries and deaths, on a no-fault basis, on the one side and, on the other, proposing regulations to promote safety in the particular industry, appointing inspectors and, in the event of breach, enforcing the regulations against employers and workers. The exercise of those

43 See Theodor Meron "The West Bank and International Humanitarian Law on the Eve of the Fiftieth Anniversary of the Six-Day War" (2017) 111 AJIL 357.

44 Legal Consequences of the Construction of a Wall in the Occupied Palestinian Territory (Advisory Opinion) [2004] ICJ Rep 136 at 177 and 183-187.

45 Oscar M Uhler and Henri Coursier The Geneva Conventions of 12 August 1949: Commentary (International Committee of the Red Cross, Geneva, 1958) vol 4 at 5. 
important powers was subject to supervision and appellate control by government insurance offices. Kafka was a very senior member of such an office in Prague, the capital of the Kingdom of Bohemia, which was then known as "the Manchester of the Austro-Hungarian Empire". A recent book of his office writings shows him dealing with businesses which were trying to get into a less expensive risk category, resolving particular compensation claims, trying to improve safety standards, for instance in quarries - recall the way in which Josef K was killed at the end of The Trial - and after 1914 becoming increasingly concerned about the rehabilitation of the many servicemen wounded in the Great War and the establishment of psychiatric hospitals for them - one was proposed for the town of Frankenstein. ${ }^{46}$

The composition of those associations must have had a real influence on those who in 1919 at Versailles drafted the Constitution of the International Labour Organization, included in all the peace treaties concluded after the Great War. ${ }^{47}$ That Constitution provides for tripartite representation of each of the now 187 members. The Conference which adopts international labour conventions - now almost 200 of them - is composed of national delegations consisting of two government delegates, one representing employers and one representing workers. The Governing Body, now of 56 persons, also has a tripartite membership. Those responsible for preparing the Constitution in 1919 justified the establishment of the new organisation in this way: ${ }^{48}$

... universal and lasting peace can be established only if it is based upon social justice;

And ... conditions of labour exist involving such injustice, hardship and privation to large numbers of people as to produce unrest so great that the peace and harmony of the world are imperilled; and an improvement of those conditions is urgently required ...

No doubt delegates had very much in their mind the Russian Revolution which had occurred less than two years earlier and the economic and social turmoil across much of Europe at that time.

They provided a non-exhaustive list of 11 examples of the areas in which improvement was required and set out general principles, one of which was that men and women should receive equal remuneration for work of equal value. ${ }^{49}$ As with the two labour conventions adopted in $1907,{ }^{50}$ they

46 Stanley Corngold, Jack Greenberg and Benno Wagner (eds) Franz Kafka: The Office Writings (Princeton University Press, Princeton, 2009) at chs 5, 9, 14 and 16-17.

47 Constitution of the International Labour Organization 15 UNTS 40 (signed 28 June 1919, entered into force 10 January 1920).

48 Preamble.

49 Compare Roberts v Hopwood [1925] AC 578 (HL) especially at 594: the unlawfulness of being "guided ... by a feminist ambition to secure the equality of the sexes in the matter of wages in the world of labour".

50 International Convention respecting the Prohibition of the Use of White (Yellow) Phosphorus in the Manufacture of Matches, above n 10; and International Convention respecting the Prohibition of Night Work for Women in Industrial Employment, above n 10. 
recognised the need for international regulations because the failure of any nation to adopt humane conditions of labour is an obstacle in the way of other nations which desire to improve the conditions in their own countries.

In 1944 the International Labour Conference, under the chairmanship of Walter Nash and with President Roosevelt in attendance, adopted what has become known as the Declaration of Philadelphia. ${ }^{51}$ Building on the 1919 text it reaffirmed the fundamental principles on which the International Labour Organization (ILO) is based: ${ }^{52}$

(a) labour is not a commodity;

(b) freedom of expression and of association are essential to sustained progress;

(c) poverty anywhere constitutes a danger to prosperity everywhere;

(d) the war against want requires to be carried on with unrelenting vigour within each nation, and by continuous and concerted international effort in which representatives of workers and employers, enjoying equal status with those of governments, join with them in free discussion and democratic decision with a view to the promotion of the common welfare.

Some of that wording may be related to Roosevelt's Four Freedoms Speech of $1941,{ }^{53}$ the Atlantic Charter of $1941^{54}$ and the Declaration by the United Nations of $1942 .{ }^{55}$ It is striking just how much principled thinking can occur in the midst of dreadful wars. That is also to be seen in the detailed report on social insurance prepared by William Beveridge in 1942 in the United Kingdom. His first principle includes the proposition that a "revolutionary moment in the world's history is a time for revolutions, not for patching". 56

Very early in its existence, under the enthusiastic leadership of Albert Thomas, its first director, ${ }^{57}$ the International Labour Conference adopted conventions on workers' compensation, among many others. As with the League of Nations, New Zealand took very little interest in the ILO until 1935 and

51 Declaration concerning the Aims and Purposes of the International Labour Organization (adopted 10 May 1944) [Declaration of Philadelphia].

52 Article 1

53 Franklin Roosevelt, President of the United States "1941 State of the Union Address" (Washington DC, 6 January 1941).

54 Atlantic Charter 204 LNTS 382 (14 August 1941).

55 Declaration by United Nations 204 LNTS 382 (1 January 1942).

56 William Beveridge Social Insurance and Allied Services (20 November 1942) at 6 [Beveridge Report].

57 A major biography by one of his successors is entitled Yes and Albert Thomas: Edward J Phelan Yes and Albert Thomas (Cresset Press, London, 1936). 
the election of the First Labour Government. In 1938 it became party to 21 conventions, including three relating to workers' compensation. ${ }^{58}$

Again I have got ahead of my chronology. I go back to 1896 to the Brunner Mine disaster which killed all 65 miners working there. ${ }^{59}$ They left 39 widows and 192 children as well as elderly dependents. The funds available from a government-imposed levy on coal production and from the friendly societies formed through the miners' unions were not adequate to cover the costs of such tragedies. The first workers' compensation statute was passed in $1900{ }^{60}$ The New Zealand debates about compensation for personal injury and the legislative changes and proposed reforms from 1900 through to the 1970s have been extensively reported and debated in official publications, law conference proceedings and scholarly writing. ${ }^{61}$ That is also the case concerning the Woodhouse Report, its reception, the initial and later legislation, the various reviews of the operation of the scheme, amendments to it and ongoing commentaries on its administrative efficiency - the fifth of the principles in the Report submitted 50 years ago.

I would expect that in future lectures in this series and in the associated symposia some of that experience will be reviewed in a wider context as Sir Owen would have wished. ${ }^{62}$ Consider the coverage of disability caused by illness, the concept of a minimum income and an overall approach to preventing harm. I will draw three lessons from the last 50 years of that material, but before I do that I may be allowed to mention my first meeting with the Judge as his Royal Commission was getting underway. It was in the Auckland Law School Library at the back of Pembridge. Professor Jack Northey, the Dean of the Auckland Law School, introduced me. It was the first substantive discussion I had ever had with a judge and I think he suggested that law faculty members might take an interest in his inquiry. He certainly did make that suggestion to Professor Colin Aikman, the Dean of Law at

58 See Ministry of Foreign Affairs and Trade New Zealand Consolidated Treaty List as at 31 December 1996: Part One (Multilateral Treaties) (1 July 1997). At that point the Conference had adopted 62 conventions.

59 See for example Hazel Armstrong Blood on the Coal: the origins and future of New Zealand's Accident Compensation scheme (rev ed, Trade Union History Project, Wellington, 2008).

60 The Worker's Compensation Act 1990.

61 See especially Geoffrey Palmer Compensation for Incapacity: A Study of Law and Social Change in New Zealand and Australia (Oxford University Press, Wellington, 1979); and Ian Campbell Compensation for Personal Injury in New Zealand: Its Rise and Fall (Auckland University Press, Auckland, 1996). They make extensive reference to the proposals, debates and actions. Armstrong, above n 59, provides some of the updating.

62 To take just one instance, consider the work of the Groupe de réflexion (Think tank) on the future of social security set up by the ILO in the early 1980s. The group included Brian Abel-Smith, Professor of Social Administration at London School of Economics and Political Science, others with experience in social insurance and security and Owen Woodhouse. See Matthieu Leimgruber "The Embattled Standard-bearer of Social Insurance and Its Challenger: The ILO, the OECD and the 'Crisis of the Welfare State', 1975-1985" in Sandrine Kott and Joëlle Droux (eds) Globalizing Social Rights: The International Labour Organization and Beyond (Palgrave MacMillan, London, 2013) 293. 
Victoria University at that time, and four of us duly presented ourselves and later realised that we were to a large extent on the same wavelength as the Judge, at least. With the Social Welfare Department and some individuals, the Victoria University team - Colin Aikman, Ivor Richardson, Peter McKenzie and I - were the only submitters supporting a universal scheme. With the Department, we received recognition in the Woodhouse Report. ${ }^{63}$ Would that count for the Performance-Based Research Fund?

As I recalled at a 2003 conference, addressed by opponents as well as supporters of the scheme, I was influenced in my thinking by the teaching in the legal system course at Victoria University of the law relating to work injuries, a course which began with Priestley $v$ Fowler, the patchwork of inadequate and chancy common law and legislative remedies, a matter emphasised by Terence Ison's then recent book The forensic lottery: a critique on tort liability as a system of personal injury compensation, ${ }^{64}$ the preamble to the Social Security Act 1938 enacted in the year New Zealand accepted the ILO conventions on workers' compensation (conventions mentioned in the terms of reference for the Royal Commission because New Zealand was not in compliance with them, notably with its six-year limit on compensation) and the principles underlying the 1942 Beveridge Report.

The first of my three lessons from the last 50 years of debate and action since the Woodhouse Report was published concerns the questions to be asked and answered. As the 1897 article with which I began said and the 1967 report confirmed, injury prevention should be divided from the rehabilitation and compensation of the injured or their dependants. Next, incapacity should not be limited to injuries at work, nor indeed to workers, the position taken by Parliament after the change of government in 1972. In principle the scheme should include incapacity caused by illness - a step which was the subject of study, including careful costings, submissions and proposals in the late $1980 \mathrm{~s},{ }^{65}$ but which unfortunately has yet to be taken. Principle cannot justify the distinction drawn between the entitlements of those who lose their leg in a car accident or through cancer. It is encouraging that that matter is still being pursued.

A second lesson, yet again, is about taking the facts seriously - to quote the subtitle of a 1996 book by three Canadian scholars (one also a New Zealander). ${ }^{66}$ They reviewed the evidence, largely from North America, on the efficiency of the tort system and its alternatives relating to automobile accidents, medical accidents, product-related accidents, environmental injury and work place injuries. They wished to move away from theoretical debates about the appropriate normative goals of the tort

63 Woodhouse Report, above n 5, at [169].

64 Terence G Ison The forensic lottery: a critique on tort liability as a system of personal injury compensation (Staples Press, London, 1967).

65 See especially Rehabilitation and Incapacity Bill 1990 (45-1); and Occupational Safety and Health Bill 1990 (34-1).

66 Don Dewees, David Duff and Michael Trebilcock Exploring the Domain of Accident Law: Taking the Facts Seriously (Oxford University Press, New York, 1996). 
system and the doctrinal implications that each entails. For them the principal goals are deterrence, compensation and corrective justice. The tort system, they conclude, cannot successfully achieve all three. The empirical evidence leads them to a bleak judgement, their words, about the tort system as a compensatory mechanism. They have real doubts about deterrence; those conclusions had already been reached by the Royal Commission in 1967 and were confirmed by the Law Commission in $1988 .{ }^{67}$ Both processes were assisted by extensive submissions $-1,698$ in the 1988 exercise - and by expert consultants - Mr IB Campbell, who later completed a $\mathrm{PhD}$ and book on the whole matter, ${ }^{68}$ on safety and related issues, Professor LV Castle on underlying economic and public policy principles and Mr JR Cumpston and Dr RC Madden on actuarial and policy matters. Other important questions and facts are comparative. I mention two questions:

(1) What proportion of GDP does the scheme absorb? It is still under two per cent, a proportion which over the years has been less than the proportion of Australia's GDP absorbed by workers' compensation and road traffic injury premiums which have a more limited coverage. ${ }^{69}$

(2) How do the administrative costs of operating the New Zealand scheme compare with those of other schemes? Administrative costs are usually under 10 per cent of the premium and related income, compared with up to 30 per cent in other schemes.

Such questions about facts along with many others need to be addressed and systematically answered and not just by the Accident Compensation Corporation. The recent Otago studies are encouraging in this respect. ${ }^{70}$

A third lesson concerns the need for bipartisan support and for the fostering of that support. Over the years I have seen too much political bickering with insufficient attention being given to the facts and to the underlying policies and principles. Am I being too optimistic in drawing positive lessons from the very brief life of the privatisation of injury insurance in the early 1990s and indeed of the non-use since then of the word "insurance" and the failure of the incoming Government to give effect to the policy it had announced in 2008 of re-establishing a competitive market to provide accident insurance? The independent review undertaken by PricewaterhouseCoopers the following year may

67 Law Commission, above n 28, at [79]-[80].

68 Campbell, above n 61.

69 See for example Law Commission, above n 28, at [16].

70 See Aclaim Otago Understanding the Problem: An analysis of ACC appeals processes to identify barriers to access to justice for injured New Zealanders (The New Zealand Law Foundation and University of Otago, 9 July 2015); and Warren Forster, Tom Barraclough and Tiho Mijatov Solving the Problem: Causation, transparency and access to justice in New Zealand's personal injury system (The New Zealand Law Foundation and University of Otago, 22 May 2017). 
have helped reason and facts to prevail. ${ }^{71}$ The review concluded that the current highly regarded ACC scheme is consistent with the Woodhouse principles, adds considerable value to New Zealand society and performs very well in comparison to alternative schemes in operation internationally. ${ }^{72}$

Next, what is to be made of the effects of the 2015 amendments to the legislation concerning financial responsibility and transparency, which are highlighted in the 2016 Annual Report of the $\mathrm{ACC},{ }^{73}$ or of the major changes to occupational health and safety law? On the latter, are we at last getting better statistics about prevention with better descriptions leading to better prescription?

I trust that I have given a sense of some of the lessons that Sir Owen in his person and in his work has taught to this country's great advantage. He drew on the wisdom of the ages, on strong values and wide experience. He was a great New Zealander. I have struggled with how, to end this lecture, I might use the words of Hotspur, the young Percy, when he was fostering the successful rebellion against Richard II in favour of Henry IV. But instead I end with the words of one of his naval colleagues and very good friends - Owen had so many - and a notable New Zealander, Lieutenant Commander Denis Glover. They are words which I attempted to have included in what was to be a unanimous judgment of the Court of Appeal, after Owen's time, but unsuccessfully: ${ }^{74}$

I do not dream of Sussex downs

Or quaint old England's quaint old towns:

I think of what will yet be seen

In Johnsonville and Geraldine.

71 PricewaterhouseCoopers Accident Compensation Corporation: Scheme review (March 2008).

72 At xviii.

73 Accident Compensation Corporation Annual Report 2016 (ACC7569, October 2016) at 4.

74 Denis Glover "Home Thoughts" Tomorrow (New Zealand, 21 August 1935) at 16. As Brian Easton carefully notes, when the poem reappeared in 1981 the word "will" was replaced by "may", a change which "may reflect the rising caution of age, and a disillusion with the possibilities of being a New Zealander": The Nationbuilders (Auckland University Press, Auckland, 2001) at 141. 